\title{
Bets are placed for next Harvard president
}

The repercussions of Larry Summers's resignation as Harvard president are being felt both within and beyond the university's courtyards. His exit has cast a shadow on plans to promote science at the institution, and highlights the challenges faced by university leaders worldwide.

Summers's announcement on 21 February that he will step down in June marked the climax of a year of intense criticism from academics unhappy with his brusque leadership and lack of consultation with faculty. Former Harvard president Derek Bok will stand in as interim leader until a new president is chosen.

Summers's departure leaves some Harvard scientists in a state of disquiet. One of his central ambitions for the university was to develop the sciences, particularly interdisciplinary research, which he viewed as essential for Harvard to remain at the forefront of academia (see Nature 433, 190-192; 2005). "There is a sense of unease," says David Scadden, co-director of the Harvard Stem Cell Institute, one of the projects championed by Summers. "We want the successor to share his sense of priority."

One of Summers's boldest plans was to place science facilities at the core of a vast new campus to be built in Allston, Boston. Just days before his resignation, the university unveiled concrete plans for the first building on the Allston campus, a 46,450-square-metre complex that will house the Stem Cell Institute among other science initiatives.

Steven Hyman, Harvard provost and top administrator, told Nature that expansion of science remains a main priority for the Harvard Corporation, the governing body responsible for selecting Summers's successor. ${ }^{\circ}$ The university remains absolutely committed to a vision of building science at Harvard, he says. But because most details have yet to be thrashed out, some academics say Summers's departure provides an opportunity to reassess the plans, for example, which areas of research merit investment. "There are concerns about the direction to go and "The university remains how fast to go," says physiabsolutely committed cist Gary Feldman, one to vision of Summers's critics. "We to a vision of building science at Harvard." need a careful and impartial assessment of Harvard's needs."

With so much at stake, all eyes are on the selection process for the next president. Many faculty chafed at Summers's corporate management tactics - he previously served as US treasury secretary. The selection committee

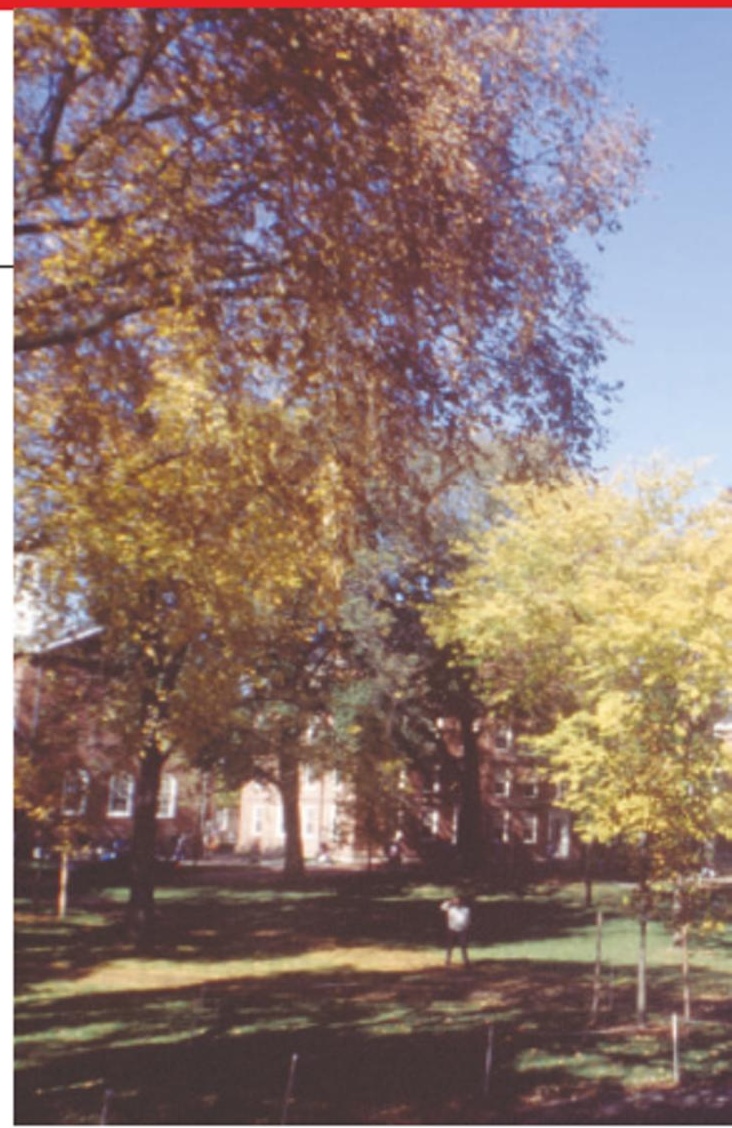

Who next? Harvard scientists are hoping the next university president continues to prioritize science.

will therefore probably choose someone already senior at another university or from within Harvard, predicts William Funk of executive recruitment firm Korn/Ferry International, who helps universities find new presidents. "I think this time they'll be very risk averse and choose someone steeped in academe with a proven track record," he says.

Because of Harvard's position at the pinnade of the US university system, Summers's resignation is attracting intense scrutiny from academics nationwide. They say Summers's

\section{Scepticism greets EU plan for virtual institute}

\section{MUNICH}

Plans announced last week to create a European Institute of Technology (EIT) have received a lukewarm reception from the scientific community.

The new body is being touted as the European counterpart of the US Massachusetts Institute of Technology (MIT). It will aimto translate research into commercial opportunities andjobs. Butmany are sceptical about what the 'virtual' institution, which would consist of partnerships betweenacademic and industry research groups across Europe, is likely to achieve.
José Manuel Barroso, president of the European Commission, outlinedplans for the ET on 22 February. He said it would be "a light and flexible organization" that will foster education, research and innovation in commercially promising fields of science. But he gave few details about how much the institute is likely to cost, or the research areas it will target.

A proposal to create a centre for the EIT in the European parliament building in Strasbourg was discarded, mainly because choosing a single site would have been interpreted as favouring a particular country or region. So the institute will be made up of partnerships in which members of research groups working on a particular area will spend time in each others' labs. If approved by the European Council later this month, the initiative could be up and running by 2010 .

Butscientists doubt that the proposednetwork will yieldanything as efficient as MIT, with its annual budget of $\$ 2$ billion. The proposed structure is scarcely different from research collaborations already funded by the European Union, says Renzo Rubele, a theoretical physicist at the University of Salerno in Italy, and a member of an expert group on university research. Tomake a real difference, he adds, wouldrequire a powerhouse like the particle-physics lab CERN in Geneva, Switzerland, where people and ideas are continuously exchanged.

Science managers are also unconvinced. "In principle, a European MIT would be a good thing. Butat this stage it is an illprepared political rush job," says Helga Nowotny, vice-president of the scientific council of the proposed European Research Council and former chair of the European Research Advisory Board. 


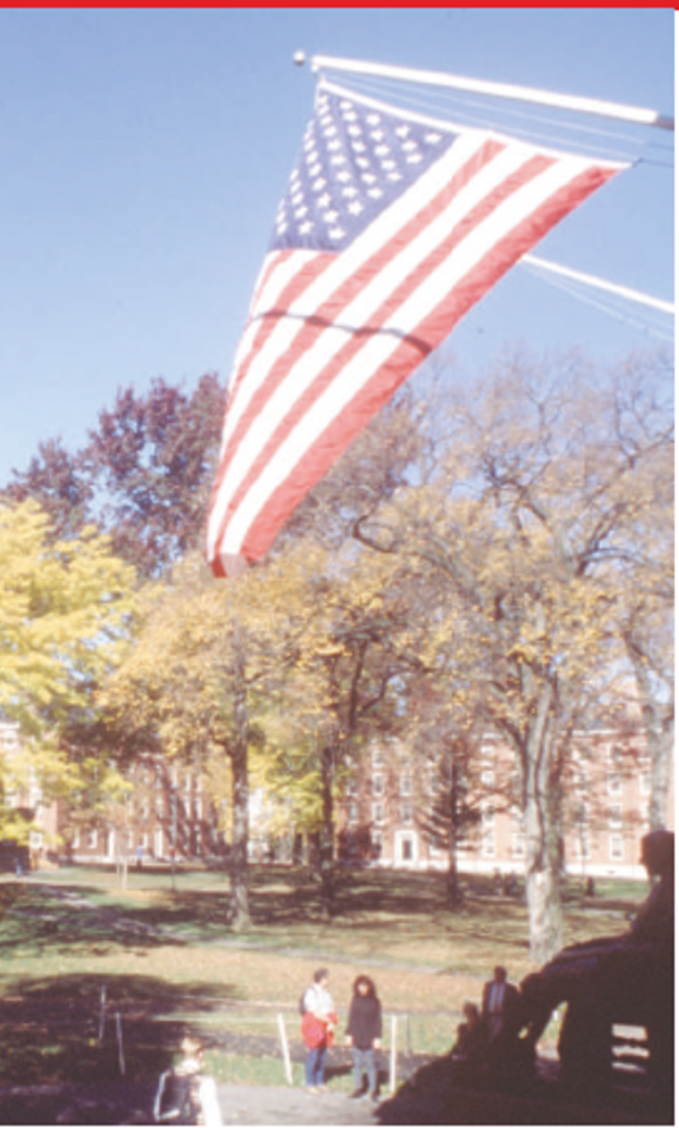

run-ins with faculty reveal the difficulties faced by a modern university leader, who must increasingly spend time away from campus raising funds and liaising with the wider community.

Although it is easy to develop sweeping plans, a good director must be able to sell them to faculty and staff, says Ingrid Moses, chancellor of the University of Canberra, Australia, and former president of the International Association of University Presidents. ${ }^{\alpha}$ They are the ones who are crucial for implementation," she says, "hence the importance of interpersonal skills." Helen Pearson

"What Europe really lacks in terms of innovation is sufficient venture capital for spin-off companies," she says. "The EIT cannot solve that problem."

Nowotny adds that althoughclusters of academicandindustrial research work well at the regional level, she doesn't believe sending industry researchersto distant university labs will boostinnovation. Barroso is confident that industry will take the bait, however. This could be crucial for the ET, as it is still unclear how the institute will be financed.

Several European companies, including Pirelli and Nokia, have welcomed the idea, buthave notspecified what they might contribute. Help may also be on the way from across the Atlantic: Microsoft founder Bill Gates has signalled that his foundation intends to support the research flagship. Quirin Schiermeier

\section{Rules tighten for stem-cell studies}

Researchers have taken a first stab at clarifying the conflicting rules that govern stem-cell research. A panel of more than $\mathbf{5 0}$ scientists, journal editors and ethicists have produced guidelines that they hope will promote international collaborations in a field badly shaken by the South Korean cloning scandal.

In Germany, most stem-cell research is illegal, and researchers could in theory be jailed if they participate in embryo experiments abroad. China lacks clear national policies, with different institutes following different rules. Laws also differ between US states. "The situation is likely to get worse," adds Robin Lovell-Badge, a stemcell biologist at the National Institute for Medical Research, London, and member of the panel. He says even countries with welldeveloped laws must continually update them to cope with emerging techniques.

The panel will set up a website where researchers can explain local laws and share existing ethical guidelines. It also wants journal editors to ask authors for more information relating to the ethics of the research they publish, such as the source of cells, to encourage the development of transparent ethical standards.

The group stresses the importance of obeying national laws, but calls on countries such as Germany to reconsider legislation that extends to research elsewhere. "Laws all around the world are stopping international collaboration," says panel member Julian Savulescu, an ethicist at the University of Oxford, UK.

The meeting, which took place over 22-24 February in Hinxton, UK, took two years to plan. It was not designed to tackle fraud, such as the case of Woo Suk Hwang, the South Korean scientist who faked data showing stem cells could be extracted from cloned human embryos. But the group does propose that egg donors are treated in the same way as human research subjects, meaning that Hwang's use of eggs from his researchers would probably not have been approved.

The group plans to meet again, probably within two years, to discuss new technologies such as chimaeras.

Jim Giles

For the Hinxton Group's statement

[wwwnature.com/news/2006/06022] full/440009a 